\title{
Karakterisasi Tingkat Produksi Duku Berbasis Pewilayahan Hujan di Provinsi Jambi
}

\author{
Characterization of Duku Production Levels Based on Zoning of Rainfall Pattern \\ in Jambi Province
}

\author{
Fendy Arifianto $^{1}$, Yonny Koesmaryono ${ }^{1}$, dan $\operatorname{Impron}^{1}$ \\ Diterima 08 April 2016/Disetujui 06 Juli 2016
}

\begin{abstract}
Duku (Lansium domesticum Corr) is one of tropical fruits and of high economic value. The Jambi provincial government works to maintain and develop duku production through improvement of cultivation and expansion. The supporting factor for success of duku production was the weather especially precipitation. This study was conducted to obtain precipitation characteristics on land suitability of duku productivity in Jambi Province. The results showed that the rainfall pattern in Jambi province had five characters in which the annual precipitation $2583 \mathrm{~kg}^{\mathrm{tree}} \mathrm{e}^{-1} \mathrm{yr} \mathrm{r}^{-1}$. The average of duku productivity in rainfall pattern I dan II was $269 \mathrm{~kg} \mathrm{tree}^{-1} \mathrm{yr}^{-1}$, and the other result outside rinfall pattern I and II had the average productivity $370 \mathrm{~kg} \mathrm{tree}^{-1} \mathrm{yr}^{-1}$.
\end{abstract}

Key words: duku, Jambi Province,land suitability, precipitation, productivity

\begin{abstract}
ABSTRAK
Duku (Lansium domesticum Corr) merupakan salah satu buah tropis yang memiliki nilai jual yang cukup tinggi. Pemerintah Daerah Provinsi Jambi berupaya untuk mempertahankan dan mengembangkan produksi duku melalui perbaikan budidaya tanaman dan perluasan lahan. Faktor yang menjadi pendukung terhadap keberhasilan produksi suatu tanaman adalah faktor iklim terutama curah hujan dan suhu. Penelitian ini bertujuan untuk mendapatkan karakteristik curah hujan wilayah untuk kesesuaian lahan tanaman duku di Provinsi Jambi. Hasil penelitian menunjukkan bahwa pola curah hujan wilayah di Provinsi Jambi memiliki lima pola dengan curah hujan rata-rata tahunan sebesar $2583 \mathrm{~mm}^{-1 a h u n^{-1}}$. Rata-rata produksi duku di wilayah yang berpola hujan I dan II $269 \mathrm{~kg}$ pohon $^{-1}$ tahun $^{-1}$, sedangkan daerah yang diluar pola tersebut memiliki rata-rata produktivitas sebesar $370 \mathrm{~kg}$ pohon ${ }^{-1}$ tahun $^{-1}$.
\end{abstract}

Kata kunci: duku, kesesuaian lahan, presipitasi, produktivitas, Provinsi Jambi

\section{PENDAHULUAN}

Duku (Lansium domesticum Corr) termasuk salah satu primadona buah tropis dengan nilai ekonomi yang cukup tinggi. Direktorat Jenderal (Ditjen) Hortikultura Departemen Pertanian telah menetapkan duku Kumpeh sebagai varietas unggul berdasarkan Surat Keputusan Menteri Pertanian No: 101/KPTS.TP.240/3/2000 tanggal 7 Maret 2000 (BPSB Provinsi Jambi, 2002). Ditjen Hortikutura (2009) menyatakan perlu adanya strategi peningkatan produksi dan mutu yang dapat mendukung pengembangan suatu komoditas tanaman unggulan. Penelitian mengenai aspek sosial ekonomi dan potensi agribisnis perlu dilakukan untuk mendapatkan informasi dan menganalisis aspek terkait pada komoditas tertentu (Pratomo dan Andri, 2013). Informasi curah hujan sangat penting dan dibutuhkan oleh hampir semua bidang seperti pertanian, transportasi, perkebunan, hingga untuk peringatan dini bencana alam, banjir, longsor dan kekeringan (Parwati et al., 2009). 
Keberhasilan pengembangan dan budidaya suatu komoditas ditentukan oleh teknologi budidaya serta kesesuaian sumber daya lahan dan iklim agar tercapai jumlah dan mutu yang diharapkan (Estiningtyas, 2001).

Curah hujan merupakan unsur iklim yang terpenting dalam budi daya tanaman duku (Hernita et al., 2006). Dalam menanam duku, sumber daya lahan dan iklim merupakan salah satu informasi yang penting untuk diperhatikan karena merupakan faktor yang sangat berpengaruh terhadap pertumbuhan dan produksi tanaman duku (Purnama et al., 2010).

Jumlah stasiun pengamatan curah hujan yang ada di wilayah penelitian terkadang hanya sedikit. Untuk mengestimasi curah hujan wilayah yang tidak memiliki stasiun pengamatan curah hujan dibutuhkan sebuah teknik untuk estimasi curah hujan. Estimasi sebaran secara spasial dari data stasiun pengamatan hujan dengan Sistem Informasi Geografi (SIG) umumnya menggunakan teknik interpolasi.

Manfaat dari pewilayahan hujan menggunakan interpolasi selain dapat menduga curah hujan di suatu daerah yang tidak memiliki stasiun hujan juga dapat digunakan untuk mengetahui karakteristik curah hujan dalam kaitannya untuk pengembangan suatu komoditas tanaman. Berdasarkan hal tersebut penelitian ini bertujuan untuk mendapatkan karakteristik curah hujan untuk kesesuaian lahan tanaman duku di Provinsi Jambi.

\section{METODE PENELITIAN}

\section{Waktu dan Tempat}

Pemilihan lokasi penelitian dilakukan secara sengaja (purposive) di Provinsi Jambi. Kegiatan penelitian dilakukan mulai bulan Juli 2014 sampai Februari 2015

\section{Data dan Sumber Data}

Data curah hujan harian dari 28 pos pengamatan hujan mulai 2000 sampai dengan 2013 di Provinsi Jambi (Sumber: Stasiun Klimatologi Sei Duren Jambi, Pusair PU dan Disperta Provinsi Jambi). Data produktivitas tanamana duku Provinsi Jambi tahun 2003 2013 (Sumber: Disperta Provinsi Jambi). Peta pengunaan lahan (Rupa Bumi Indonesia) Skala 1: 2500000. (Sumber: Bakosurtanal, 2001).

\section{Penyusunan Peta Jambi dan Sebaran Stasiun Hujan}

Tahap awal adalah pembuatan peta dasar yang akan dijadikan acuan untuk peta lainnya yaitu peta Jambi dan sebaran stasiun hujan yang disusun dari peta administrasi (ID kabupaten dan kecamatan) dan lokasi stasiun (lintang, bujur dan ketinggian). Untuk menentukan posisi stasiun terpilih (lintang dan bujur) digunakan peta rupa bumi (RBI) dengan skala 1: 250000.

\section{Pengolahan Data Curah Hujan}

Proses pertama kali yaitu pengumpulan data curah hujan yang ada di tiap stasiun curah hujan Provinsi Jambi. Selanjutnya data diseleksi dengan melihat kualitas data dan sebaran stasiun yang digunakan untuk analisis pewilayahan. Tahapan seleksi tersebut mencakup pemilihan stasiun yang memiliki data kontinyu dengan panjang catatan data tidak kurang dari 10 tahun. Data curah hujan bulanan dan tahunan dari stasiun yang terpilih selanjutnya digunakan untuk analisis tipe iklim menurut metode yang dikembangkan oleh Schmidt-Ferguson (1950).

\section{Pengolahan Data Produksi Duku}

Data produksi yang digunakan untuk analisis klasifikasi tingkat produksi adalah data beberapa kabupaten yang ada di Provinsi Jambi, yaitu Muaro Jambi, Batanghari, Merangin, Sarolangun, Tebo, Bungo, Tanjung Jabung Timur, Tanjung Jabung Barat. Data yang digunakan adalah produksi berupa hasil produksi (kg) dari tahun 2004 - 2013 dan banyak pohon dipanen (pohon) tahun 2004 2013. Langkah pertama adalah membuat ratarata tahunan dari setiap data yang diperoleh, sehingga diperoleh rata-rata produktivitas duku pertahun dalam kg pohon ${ }^{-1}$ tahun $^{-1}$.

\section{Analisis Data \\ Analisis Pewilayah Pola Hujan dan Tipe Iklim}

Untuk memperoleh informasi curah hujan di suatu daerah yang tidak memiliki stasiun hujan dapat menggunakan data dari stasiun lain yang berdekatan. Oleh karena itu, perlu pertimbangan keterwakilan satu stasiun 
yang dapat mewakili suatu wilayah atau terkait dengan stasiun lainnya. Homogenitas data dilihat berdasarkan pertimbangan bahwa stasiun-stasiun yang terdapat dalam suatu kelompok wilayah memiliki keragaman yang sama atau hampir sama (tidak berbeda nyata). Analisis ini dikenal sebagai analisis pewilayahan hujan. Salah satu teknik yang dapat digunakan untuk pewilayah hujan dengan memperhitungkan input lain seperti jarak antar stasiun adalah teknik Sistem Informasi Geografi (SIG) (Mir'as-Avalos et al., 2007). Analisis data pada penelitian ini dilakukan pengelompokan stasiun-stasiun curah hujan dengan pendekatan analisis interpolasi metode Inverse Distance Weight (IDW) menggunakan perangkat lunak ArcGIS 10.1 .

Metoda IDW (Inverse Distance Weighted) mengasumsikan bahwa tiap titik input mempunyai pengaruh yang bersifat lokal yang berkurang terhadap jarak. Metoda ini memberi bobot lebih tinggi pada sel yang terdekat dengan titik data dibandingkan sel yang lebih jauh. Titik-titik pada radius tertentu dapat digunakan dalam menentukan nilai luaran untuk tiap lokasi.

Analisis tipe iklim dari data curah hujan 28 stasiun hujan menggunakan metode Schmidt-Ferguson. Klasifikasi ini memerlukan data bulanan paling sedikit 10 tahun. Kriteria yang digunakan adalah penentuan bulan kering, bulan lembab dan bulan basah pada masing-masing bulan setiap tahun. Penentuan tipe iklim ini menggunakan nilai $Q$ yaitu dengan persamaan sebagai berikut:

$$
Q=\frac{\text { rata }- \text { rata } B K}{\text { rata }- \text { rata } B B} \times 100 \%
$$

Dimana kriteria bulan kering (BK) adalah bulan dengan curah hujan kurang dari $60 \mathrm{~mm}$, kriteria bulan lembab (BL) dimana bulan dengan curah hujan antara 60-100 mm, dan bulan basah (BB) dengan curah hujan lebih besar dari $100 \mathrm{~mm}$. Schmidt-Ferguson menentukan jumlah BK, BL dan BB tahun demi tahun selama periode pengamatan, kemudian dijumlahkan dan dirata-ratakan. Analisis data menggunakan Microsoft Excel.

Tabel 1. Jumlah curah hujan, tipe iklim dan pola hujan di Provinsi Jambi tahun 2000-2013

\begin{tabular}{lcll}
\hline Curah Hujan & Tipe Iklim (SF) & Kabupaten & Kecamatan \\
\hline 1500 & A & Bungo & Rantau Pandan \\
& B & Tebo & Tebo Ilir \\
& & Bungo & Pelepat \\
& & Tanjung Jabung Timur & Muara Sabak Timur, Muara Sabak Barat \\
& & Tanjung Jabung Barat & Tungkal Ulu, Tungkal Ilir \\
& & Merangin & Tabir I \\
& A & Muaro Jambi & Mestong \\
& B & Merangin & Muara Limun \\
& & Jambi & Jambi Selatan \\
& & Tebo & Rimbo Bujang \\
& & Batanghari & Pemayung \\
& & Kerinci & Kayu Aro, Gunung Kerinci \\
& & Bungo & Tanah Sepenggal, Muara Bungo \\
& A & Tebo & Tebo Ulu \\
& & Sarolangun & Sarolangun \\
& & Muaro Jambi & Jambi Luar Kota \\
& B & Batanghari & Mersam \\
& & Merangin & Pemenang I \\
& & Kerinci & Keliling Danau \\
& & Merangin & Tabir Ulu \\
& & Kerinci & Batang Merangin \\
& & Batanghari & Muara Bulian, Muara Tembesi \\
& & Sarolangun & Mandiangin \\
\hline Keterangan: Sumber: Stasiun Klimatologi Sei Duren Jambi, 2014; & Pusair PU, 2014; Disperta Prov Jambi, 2014 \\
& & &
\end{tabular}




\section{Analisis Karakterisasi Curah Hujan untuk Kesesuaian Lahan Tanaman Duku}

Analisis ini dilakukan dengan melihat karakteristik pola hujan, jumlah curah hujan, dan tipe iklim wilayah untuk kesesuaian lahan tanaman duku.

\section{HASIL DAN PEMBAHASAN}

\section{Karakteristik Curah Hujan, Pola Hujan Wilayah dan Tipe Iklim}

Rata-rata curah hujan tahunan (20002013) di Provinsi Jambi adalah sebesar 2583 $\mathrm{mm}$ tahun $^{-1}$ dengan curah hujan tertinggi di Kabupatan Merangin $3210 \mathrm{~mm}_{\text {tahun }^{-1}}$ dan terendah di Kabupaten Tanjung Jabung Timur sebesar $1987 \mathrm{~mm}$ tahun $^{-1}$ (Gambar 1). Konsentrasi curah hujan tahunan tertinggi terjadi di wilayah barat dan selatan Provinsi Jambi (Kerinci, Merangin, Sarolangun, dan Batanghari), curah hujan semakin berkurang ke arah wilayah timur laut yaitu Tanjung Jabung Timur dan Tanjung Jabung Barat (Gambar 2).

Tipe iklim wilayah Provinsi Jambi terdiri atas dua tipe iklim yaitu tipe A dan B. Pewilayahan pola hujan di Provinsi Jambi menghasilkan 5 (lima) wilayah pola hujan (Gambar 2). Secara umum pola curah hujan menunjukkan bahwa puncak hujan tertinggi terjadi pada bulan Januari, sedangkan curah hujan terendah terjadi pada bulan Juli. Jika dilihat dari sebaran spasial curah hujan di Provinsi Jambi maka tampak bahwa wilayah timur Provinsi Jambi lebih kering dibanding wilayah barat. Pada dasarnya curah hujan di wilayah Indonesia didominasi oleh adanya pengaruh beberapa fenomena, antara lain sistem monsoon Asia-Australia, osilasi selatan, sirkulasi timur-barat (sirkulasi Walker), dan utara selatan (sirkulasi Hadley) serta beberapa sirkulasi karena pengaruh lokal. Aldrian (2003) mengemukakan bahwa pola hujan bulanan di Indonesia umumnya dibagi menjadi tiga tipe. Pola hujan di Pulau Sumatera didominnasi oleh polah curah hujan monsunal, salah satu provinsi yang terdapat di pulau tersebut adalah Provinsi Jambi (Hermawan, 2010; Pramudia et al., 2013).

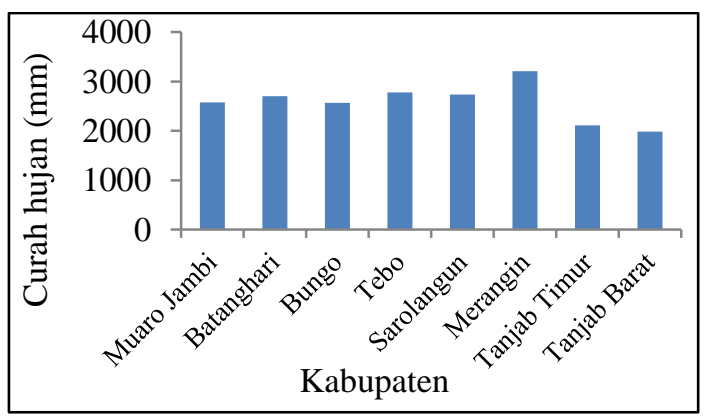

Gambar 1. Rata-rata curah hujan tahunan beberapa kabupaten di Provinsi Jambi

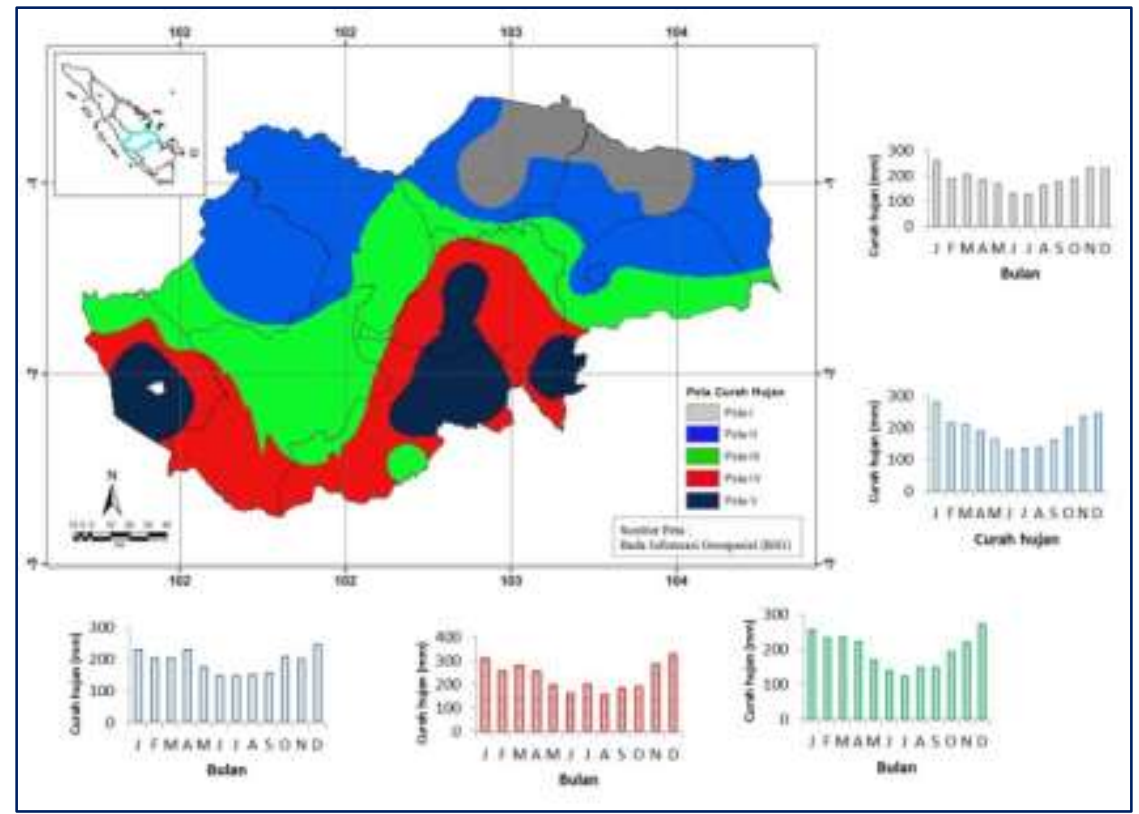

Gambar 2. Distribusi pewilayahan pola curah hujan di Provinsi Jambi 


\section{Produktivitas Duku Berdasarkan Karakteristik Curah Hujan}

Pewilayahan kriteria curah hujan untuk kesesuaian lahan tanaman duku disajikan pada Gambar 3. Wilayah hujan untuk kesesuaian lahan tanaman duku dibagi menjadi empat kelas yaitu S1, S2, S3, dan N (Djaenudin et al., 2000). Pola hujan wilayah di Provinsi Jambi terdiri atas lima pola yang ada (Tabel 2). Pola I terdiri atas Kabupaten Tanjung Jabung Timur dan Kabupaten Tanjung Jabung Barat. Wilayah pada pola ini terletak di wilayah timur Provinsi Jambi yang curah hujan pada wilayah ini lebih kecil dibandingkan dengan wilayah lain. Pola II, III, IV dan V terdiri atas sebagian dari kabupaten-kabupaten penelitian.

Produktivitas duku terendah terdapat pada wilayah yang memiliki pola I, sedangkan produktivitas duku yang tinggi terdapat pada wilayah yang memiliki pola III dan IV.

Pada umumnya setiap tanaman dan/atau kelompok tanaman mempunyai persyaratan tumbuh/hidup yang spesifik untuk berproduksi secara optimal (Djaenudin et al., 2000). Tanaman duku mulai produksi dari umur 1520 tahun hingga 120 tahun, produksi optimal pada umur 50-75 tahun (Suparwoto et al., 2005). Hasil survey didapatkan bahwa umur tanaman duku di Provinsi Jambi rata-rata berumur 3-5 tahun.

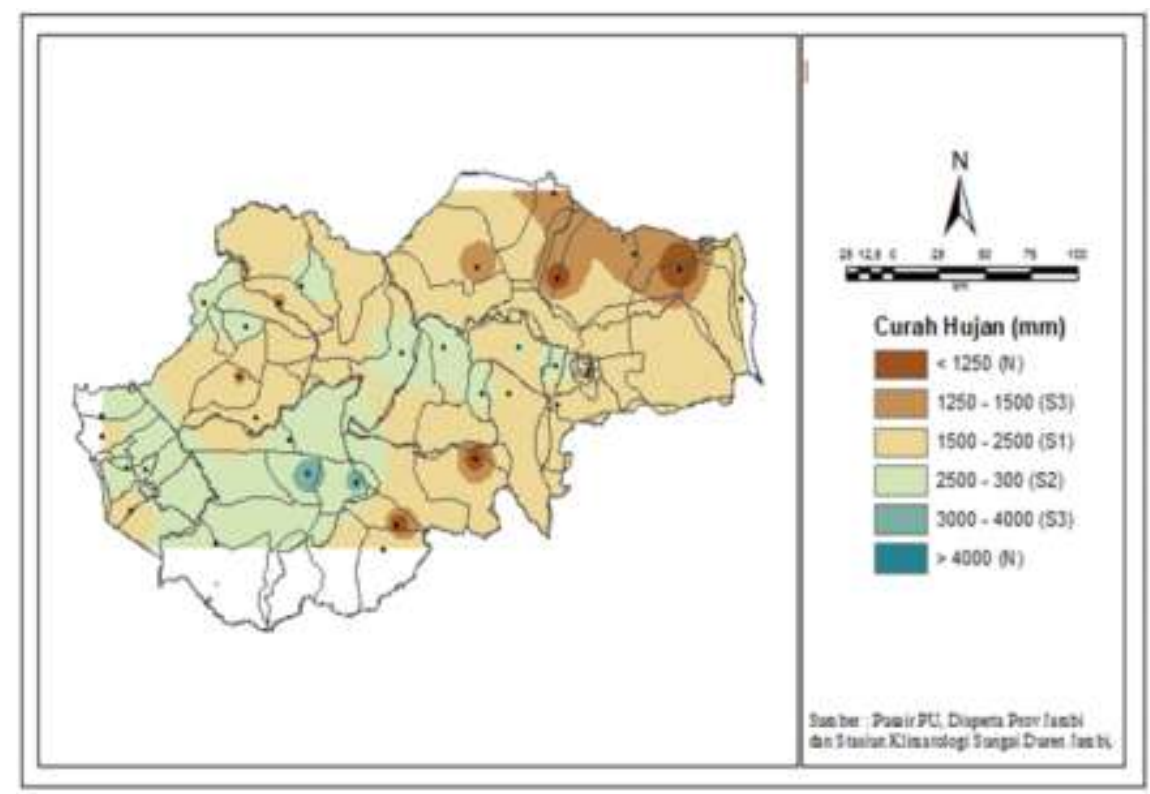

Gambar 3. Pewilayahan curah hujan untuk kesesuaian lahan pada tanaman duku di Jambi

Tabel 2. Klasifikasi tingkat produksi, kriteria curah hujan untuk kesesuaian lahan dan pola hujan di Jambi S1 = sangat sesuai, $\mathrm{S} 2=$ cukup sesuai, $\mathrm{S} 3=$ marginal sesuai, $\mathrm{N}=$ tidak sesuai

\begin{tabular}{lccc}
\hline Kabupaten & $\begin{array}{c}\text { Rata-rata } \\
\text { Produktivitas } \\
\text { (kg/pohon/tahun) }\end{array}$ & $\begin{array}{c}\text { Kriteria Curah Hujan untuk } \\
\text { Kesesuaian Lahan } \\
\text { (Djaenudin } \text { et al., 2000) }\end{array}$ & Pola Hujan \\
\hline Muaro Jambi & 380 & $\mathrm{~S} 2$ & $\mathrm{II} / \mathrm{III}$ \\
Batanghari & 356 & $\mathrm{~S} 1$ & $\mathrm{III} / \mathrm{IV} / \mathrm{V}$ \\
Bungo & 387 & $\mathrm{~S} 1$ & $\mathrm{II} / \mathrm{III}$ \\
Tebo & 322 & $\mathrm{~S} 3$ & $\mathrm{II} / \mathrm{III}$ \\
Sarolangun & 382 & $\mathrm{~S} 1$ & $\mathrm{III} / \mathrm{IV} / \mathrm{V}$ \\
Merangin & 396 & $\mathrm{~S} 3$ & $\mathrm{III} / \mathrm{IV}$ \\
Tanjab Timur & 276 & $\mathrm{~N}$ & $\mathrm{I} / \mathrm{II}$ \\
Tanjab Barat & 263 & $\mathrm{~S} 2$ & $\mathrm{I} / \mathrm{II} / \mathrm{III}$ \\
\hline
\end{tabular}




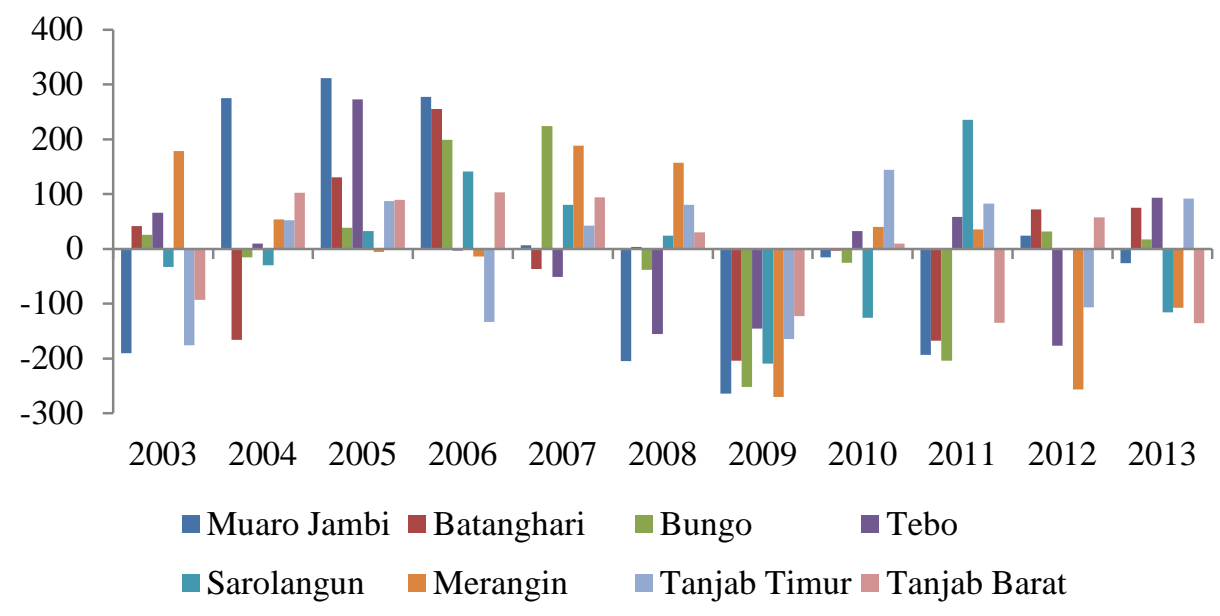

Gambar 4. Anomali jumlah curah hujan tahun 2000-2013

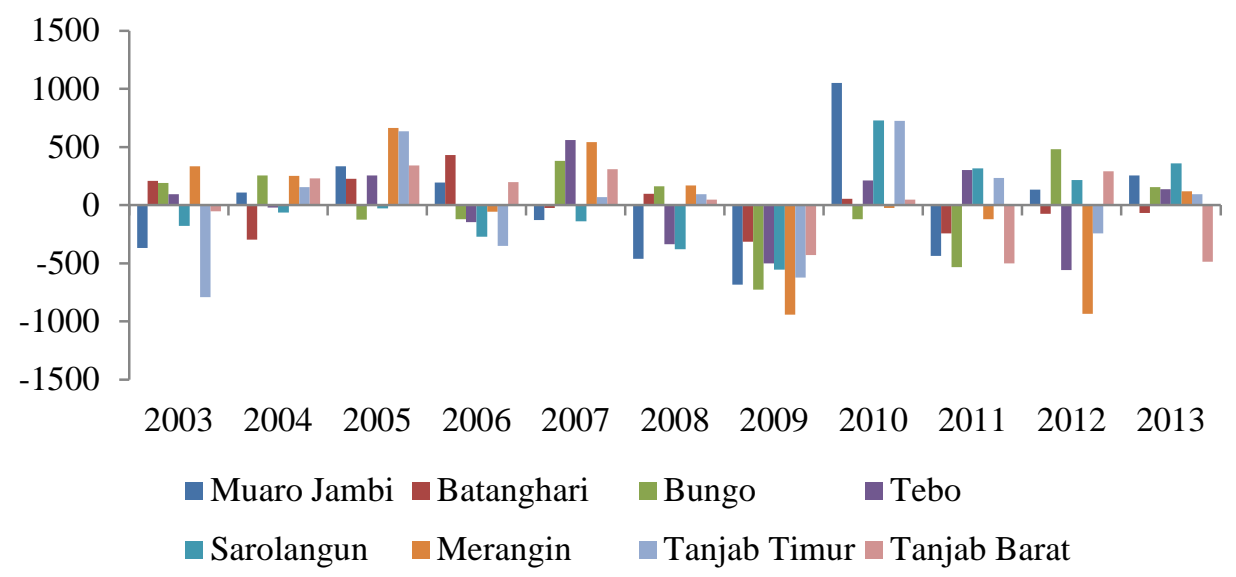

Gambar 5. Anomali jumlah produktivitas duku tahun 2004-2013

Gambar 4 dan 5 menggambarkan anomali hasil produktivitas tanaman duku tahunan dari setiap kabupaten pengamatan mengikuti pola anomali curah hujan tahunan di tiap kabupaten pengamatan. Hal tersebut menunjukkan adanya pengaruh curah hujan terhadap produktivitas tanaman duku di Provinsi Jambi. Antony (2010) menyatakan bahwa terdapat faktor lain selain curah hujan yang mempengaruhi produktivitas tanaman duku seperti suhu, kondisi tanah, ketinggian tempat serta serangan hama penyakit. Pada umumnya, faktor curah hujan lebih dominan mempengaruhi produktivitas suatu tanaman.

Pemilihan lahan untuk pengembangan tanaman duku harus diarahkan pada lahan yang sangat sesuai dan sesuai, agar pengusahaan tanaman dapat menguntungkan. Curah hujan yang dapat meningkatkan produksi tanaman duku adalah antara 2000 $3000 \mathrm{~mm} \operatorname{tahun}^{-1}$. Semakin sesuai kriteria kesesuaian lahan untuk tanaman duku semakin meningkat produktivitas tanaman.

\section{KESIMPULAN}

Karakteristik lahan Provinsi Jambi menunjukkan bahwa konsentrasi hujan terjadi di barat dan selatan Provinsi Jambi, semakin ke timur semain berkurang curah hujan yang terjadi. Hal tersebut dipengaruhi oleh variasi bentuk topografi wilayah Provinsi Jambi. Pola hujan bulanan wilayah Provinsi Jambi memiliki satu puncak maksimum yaitu pada bulan Januari. Analisis tipe iklim (SchmidtFerguson) menunjukkan bahwa Provinsi Jambi memiliki dua tipe iklim yaitu tipe A dan tipe 
B. Karakteristik curah hujan untuk produktivitas duku yang optimal adalah sebesar 2000 - $3000 \mathrm{~mm} /$ tahun dengan pola curah hujan tertinggi pada bulan Januari dan terendah pada bulan Juli.

\section{DAFTAR PUSTAKA}

Meijerink, A.M.J., H.A.M. de Brouwer, C.M. Mannaerts, C.R. Valenzuela. 1994. Introduction to The Use Of Geographic Information System For Practical Hydrology. Netherlands (NL). International Institute for Aerospace Survey and Earth Science (ITC). 243 p.

Antony, D. 2010. Strategi pengembangan komoditas duku (Lansium domesticum Corr) di kabupaten Muaro Jambi, provinsi Jambi. Tesis. Sekolah Pascasarjana Institut Pertanian Bogor.

[Balitbangtan] Badan Penelitian dan Pengembangan Pertanian. 2003. Petunjuk Teknis Evaluasi Lahan untuk Komoditas Pertanian. Balitbangtan. Bogor.

[BPSB] Badan Pengawas Sertifikat Benih Provinsi Jambi. 2002. Varietas Hortikultura Jambi. Jambi.

[Disperta Prov. Jambi] Dinas Pertanian Tanaman Pangan Provinsi Jambi. 2014. Data Pertanian Tanaman Pangan dan Hortikultura Provinsi Jambi Tahun 2013. Diperta Prov. Jambi. Jambi

Djaenudin, D., H. Marwan, Mulyani, Subagyo, Suharta. 2000. Kriteria Kesesuaian Lahan untuk Komoditas Pertanian. Pusat Penelitian Tanah dan Agroklimat Badan Litbang Departemen Pertanian. Bogor.

Djaenudin, D., H. Marwan, H. Subagjo. 2003. Evaluasi Lahan untuk Komoditas Pertanian. Pusat Penelitian Tanah dan Agroklimat Badan Litbang Departemen Pertanian. Bogor.

Estiningtyas, W. 2001. Evaluasi masa tanam dan pendugaan kehilangan hasil padi di Sukamandi: suatu pendekatan menggunakan indeks kecukupan air. Hal 331-356 Dalam Prosiding Seminar Nasional Sumberdaya Lahan dan Pupuk. Bogor, 30-31 Oktober 2001.

Hariyanti, S. Kharmila. 2010. Pewilayahan hujan dengan sistem informasi geografi untuk menganalisa tingkat produksi kakao (kasus Provinsi Sulawesi Selatan). Tesis. Sekolah Pascasarjana Institut Pertanian Bogor.

Hernita, D., N. Asni. 2006. Teknologi pemupukan duku Kumpeh. J Agron. 10: 105-108.

Eddy, H. 2010. Pengelompokkan pola curah hujan yang terjadi di beberapa kawasan Pulau Sumatera berbasis hasil analisis teknik spektral. J. Meteorology dan Geofisika. 2: 75-85.

Krzanowski, W.J. 1988. Principles of Multivariate Analysis. A User's Perspective. Oxford (GB). Clarendon Press. P 53-83.

Mir'as-Avalos, J.M., A. Paz-Gonzalez, E. Vidal-Vazquez, P. Sande-Fouz. 2007. Mapping monthly rainfall data in Galicia (NW Spain) using inverse distances and geostatistical methods. Adv. Geosci. 10: 51-57.

Parwati. 2009. Penentuan hubungan antara suhu kecerahan data Mtsat dengan curah hujan data Qmorph. J. Penginderaan Jauh Pengolah Data Digital. 6: 32-42.

Parwati, Suwarsono, A.D.S. Kusmaningayu, M. Kartasasmita. 2009. Penentuan hubungan antara suhu kecerahan data MTSAT dengan curah hujan data Qmorph. . Jurnal Penginderaan Jauh dan Pengolahan Data Citra Digital. 6: $32-42$.

Pratomo, A.G., K.B. Andri. 2013. Aspek sosial ekonomi dan potensi agribisnis bunga krisan di Kabupaten Pasuruan Jawa Timur. J. Hort. Indonesia. 4(2): 70-76. 
J. Hort. Indonesia 7(2): 121-128. Agustus 2016.

Purnama, H., A. Sutandi, Widiatmaka, K. Gandasasmita. 2010. Karakteristik lahan pada pertanaman duku (Lansium domesticum Corr) di Provinsi Jambi. J Tanah Lingkungan. 12: 18-24.

Rejekiningrum, P., A. Pramudia, Darmijati, E. Surmaini. 2003. Atlas Sumberdaya
Iklim Pertanian Indonesia. Pusat Penelitian Tanah dan Agroklimat Badan Litbang Departemen Pertanian. Bogor.

Suparwoto, Y. Hutapea. 2005. Keragaan buah duku dan pemasarannya di Sumatera Selatan. (JPPTP). 8: 436-444. 